\title{
\#USES
}

Prepared in cooperation with the National Park Service

Mountain Goat Abundance and Population Trends in the Olympic Mountains, Northwestern Washington, 2016

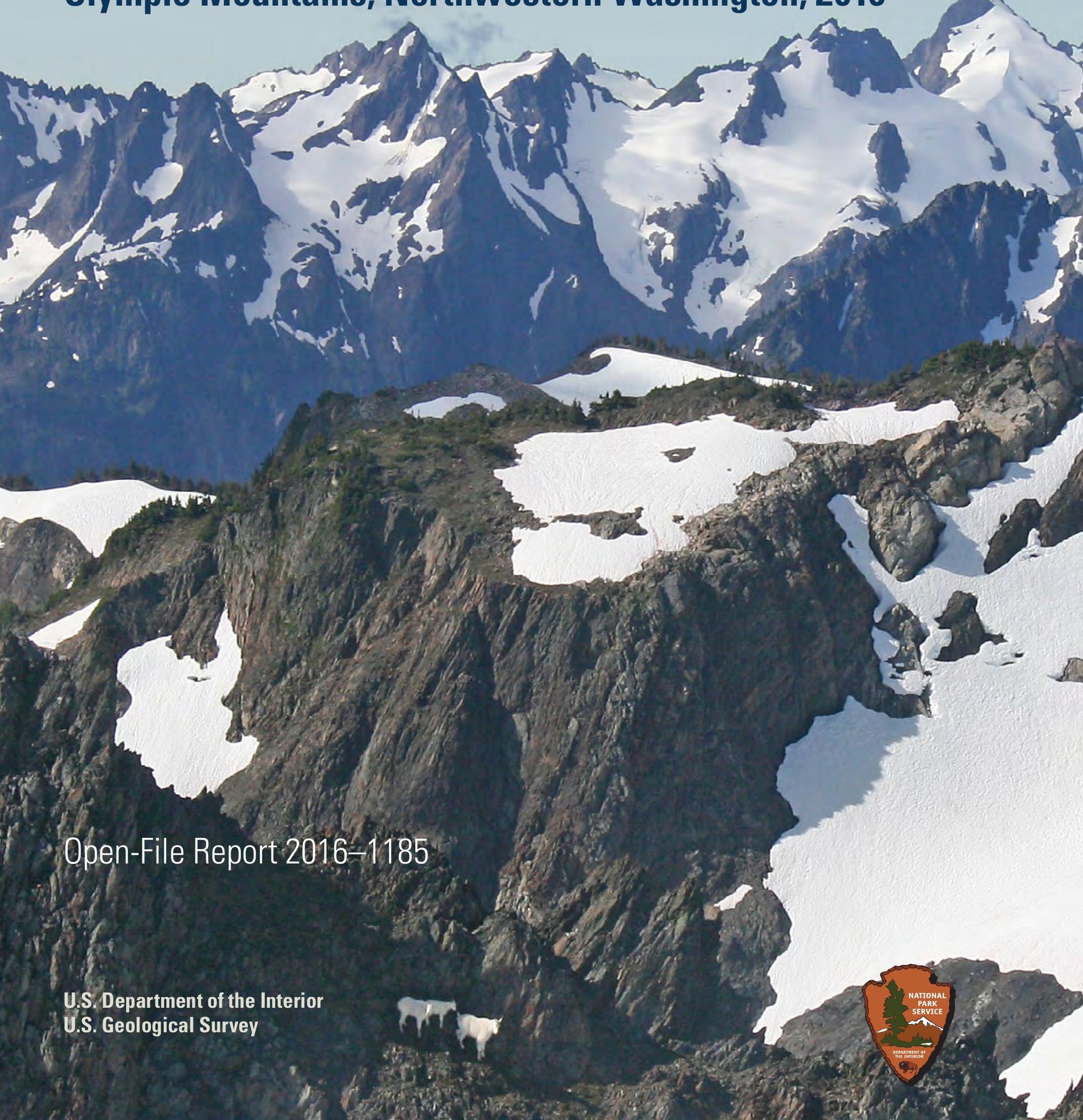


Cover: Photograph showing three mountain goats observed during aerial surveys in Olympic National Park, Washington, July 2016. Photograph by Patricia J. Happe, National Park Service. 


\section{Mountain Goat Abundance and Population Trends in the Olympic Mountains, Northwestern Washington, 2016}

By Kurt J. Jenkins, Patricia J. Happe, Katherine F. Beime, and William T. Baccus

Prepared in cooperation with the National Park Service

Open-File Report 2016-1185

U.S. Department of the Interior

U.S. Geological Survey 


\section{U.S. Department of the Interior \\ SALLY JEWELL, Secretary}

\section{U.S. Geological Survey \\ Suzette M. Kimball, Director}

U.S. Geological Survey, Reston, Virginia: 2016

For more information on the USGS—-the Federal source for science about the Earth, its natural and living resources, natural hazards, and the environment-visit http://www.usgs.gov/ or call 1-888-ASK-USGS (1-888-275-8747).

For an overview of USGS information products, including maps, imagery, and publications, visit http://store.usgs.gov/.

Any use of trade, firm, or product names is for descriptive purposes only and does not imply endorsement by the U.S. Government.

Although this information product, for the most part, is in the public domain, it also may contain copyrighted materials as noted in the text. Permission to reproduce copyrighted items must be secured from the copyright owner.

Suggested citation:

Jenkins, K.J., Happe, P.J., Beime, K.F., and Baccus, W.T., 2016, Mountain goat abundance and population trends in the Olympic Mountains, northwestern Washington, 2016 : U.S. Geological Survey Open-File Report 2016-1185, 21 p., https://doi.org/10.3133/ofr20161185.

ISSN 2331-1258 (online) 


\section{Contents}

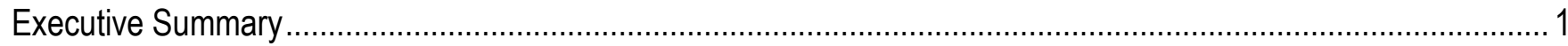

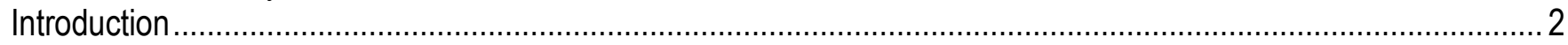

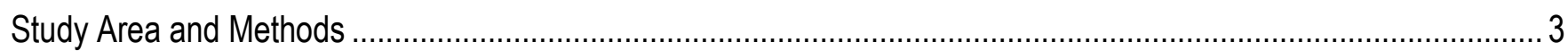

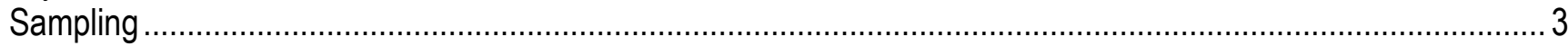

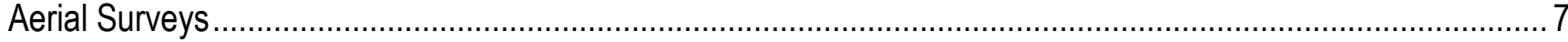

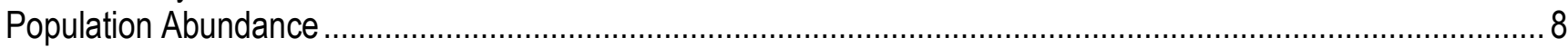

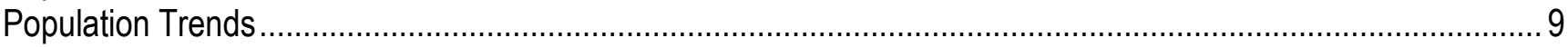

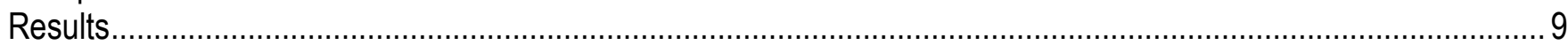

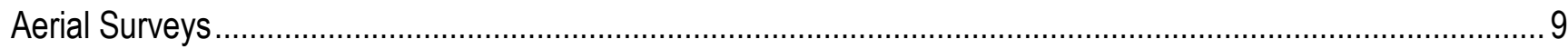

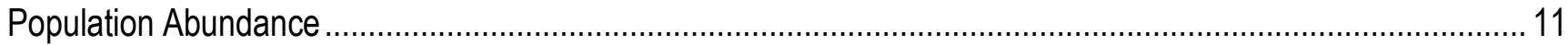

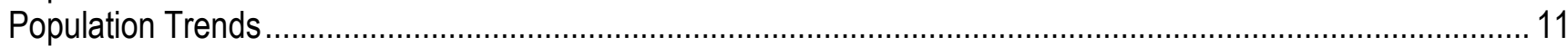

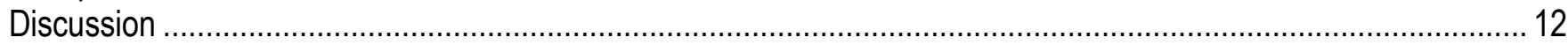

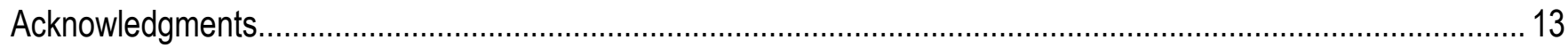

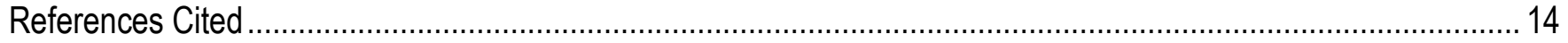

Appendix 1. Survey Flight Characteristics during Aerial Mountain Goat Surveys, Olympic Mountains,

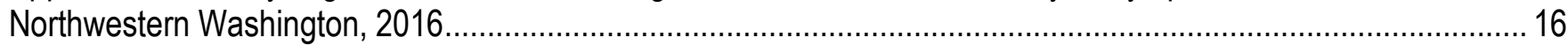

Appendix 2. Survey Characteristics and Environmental Conditions Measured at the Beginning of Each Unit Surveyed in the Olympic Mountains, Northwestern Washington, 2016.......................................................... 17

Appendix 3. Raw Counts of Mountain Goats by Survey Unit, Olympic Mountains, Northwestern Washington, 2016

\section{Figures}

Figure 1. Map showing location of study area in Olympic National Park and Olympic National Forest, northwestern Washington.

Figure 2. Map showing sampling strata, units surveyed, and number of mountain goats counted during mountain goat surveys in the Olympic Mountains, northwestern Washington, July 13-24, 2016 5

Figure 3. Graph showing trends in the minimum population index and estimated population abundance ( \pm standard error) of mountain goats in the Olympic Mountains, northwestern Washington, 1983-2016

\section{Tables}

Table 1. Mountain goat survey characteristics and raw counts of mountain goats in eight total count areas, and in high-, medium-, and low-density strata, Olympic Mountains, northwestern Washington, July 13-24, 2016.

Table 2. Population estimates of mountain goats, associated components of variance, standard errors, and 95-percent confidence intervals in the Olympic Mountains survey area, northwestern Washington, 2004-2016. 


\section{Conversion Factors}

Inch/Pound to SI

\begin{tabular}{lcl}
\hline \multicolumn{1}{c}{ Multiply } & \multicolumn{1}{c}{ By } & \multicolumn{1}{c}{ To obtain } \\
\hline foot $(\mathrm{ft})$ & Length & \\
mile $(\mathrm{mi})$ & 0.3048 & meter $(\mathrm{m})$ \\
\hline & 1.609 & kilometer $(\mathrm{km})$ \\
\hline mile per hour $(\mathrm{mi} / \mathrm{h})$ & Flight speed & \\
\hline
\end{tabular}

SI to Inch/Pound

\begin{tabular}{lcl}
\hline \multicolumn{1}{c}{ Multiply } & \multicolumn{1}{c}{ By } & \multicolumn{1}{c}{ To obtain } \\
\hline meter $(\mathrm{m})$ & Length & \\
kilometer $(\mathrm{km})$ & 3.281 & foot $(\mathrm{ft})$ \\
& 0.6214 & mile $(\mathrm{mi})$ \\
\hline hectare $(\mathrm{ha})$ & Area & \\
square kilometer $\left(\mathrm{km}^{2}\right)$ & 2.471 & acre \\
\hline & 0.3861 & square mile $\left(\mathrm{mi}^{2}\right)$ \\
\hline kilometer per hour $(\mathrm{km} / \mathrm{h})$ & Flight speed & \\
\hline
\end{tabular}

Temperature in degrees Celsius $\left({ }^{\circ} \mathrm{C}\right)$ may be converted to degrees Fahrenheit $\left({ }^{\circ} \mathrm{F}\right)$ as follows:

${ }^{\circ} \mathrm{F}=\left(1.8 x^{\circ} \mathrm{C}\right)+32$.

Vertical coordinate information is referenced to the North American Vertical Datum of 1988 (NAVD 88).

Horizontal coordinate information is referenced to the North American Datum of 1983 (NAD 83).

Elevation, as used in this report, refers to distance above the vertical datum. 


\title{
Mountain Goat Abundance and Population Trends in the Olympic Mountains, Northwestern Washington, 2016
}

\author{
By Kurt J. Jenkins ${ }^{1}$, Patricia J. Happe², Katherine F. Beirne², and William T. Baccus²
}

\section{Executive Summary}

We estimated abundance and trends of non-native mountain goats (Oreamnos americanus) in the Olympic Mountains of northwestern Washington, based on aerial surveys conducted during July 13-24, 2016. The surveys produced the seventh population estimate since the first formal aerial surveys were conducted in 1983. This was the second population estimate since we adjusted survey area boundaries and adopted new estimation procedures in 2011. Before 2011, surveys encompassed all areas free of glacial ice at elevations above 1,520 meters (m), but in 2011 we expanded survey unit boundaries to include suitable mountain goat habitats at elevations between 1,425 and 1,520 m. In 2011, we also began applying a sightability correction model allowing us to estimate undercounting bias associated with aerial surveys and to adjust survey results accordingly. The 2016 surveys were carried out by National Park Service (NPS) personnel in Olympic National Park and by Washington Department of Fish and Wildlife (WDFW) biologists in Olympic National Forest and in the southeastern part of Olympic National Park. We surveyed a total of 59 survey units, comprising 55 percent of the 60,218hectare survey area. We estimated a mountain goat population of $623 \pm 43$ (standard error, SE). Based on this level of estimation uncertainty, the 95-percent confidence interval ranged from 561 to 741 mountain goats at the time of the survey.

We examined the rate of increase of the mountain goat population by comparing the current population estimate to previous estimates from 2004 and 2011. Because aerial survey boundaries changed between 2004 and 2016, we recomputed population estimates for 2011 and 2016 surveys based on the revised survey boundaries as well as the previously defined boundaries so that estimates were directly comparable across years. Additionally, because the Mount Washington survey unit was not surveyed in 2011, we used results from an independent survey of the Mount Washington unit conducted by WDFW biologists in 2012 and combined it with the 2011 survey results to produce a complete survey conducted over 2 years. The revised estimates of mountain goat abundance occurring at elevations above 1,520 m were $230 \pm 19$ (SE) in 2004, $350 \pm 41$ (SE) in 2011, and $584 \pm 39$ (SE) in 2016. The difference between the overall 2016 population estimate ( $623 \pm 43$ [SE]) and the smaller estimate $(584 \pm 39$ [SE]) reflected the number of mountain goats counted in the expanded survey areas added in 2011. Based on comparisons within the standardized survey boundary, the mountain goat population

\footnotetext{
${ }^{1}$ U.S. Geological Survey.

${ }^{2}$ National Park Service.
} 
in the Olympic Mountains increased at an average finite rate of 6 percent annually from 2004 to 2011, 11 percent annually from 2011 to 2016 , and 8 percent annually over the combined period. We caution that the population may have been underestimated in 2011 because of record heavy snows persisting into the survey season. Therefore, the rate of population increase from 2011 and 2016 may be overestimated. The rate of increase measured over the combined period (2004-16) may be more representative of the recent population growth. We conclude that the abundance of mountain goats has increased for more than a decade, and if the recent average rate of population growth were sustained, the population would increase by 45 percent over the next 5 years.

\section{Introduction}

Mountain goats were introduced in the Olympic Mountains of Washington during the 1920s prior to the establishment of Olympic National Park (Houston, Schreiner, and others, 1994). Over the next several decades, the mountain goat population grew and expanded throughout the Olympic Mountains, leading to management concerns by the mid-1970s about the potential effects of overabundant mountain goats on soil erosion and endemic plants in high-elevation plant communities (National Park Service, 1995). In 1983, the National Park Service (NPS) conducted the first aerial survey to estimate mountain goat population size throughout the Olympic Mountains, generating an estimate of 1,175 \pm 171 (standard error [SE]) mountain goats (Houston and others, 1986). Other localized ground and aerial surveys conducted prior to 1983 did not result in complete population estimates (Houston, Schreiner, and others, 1994).

During the early 1980s, the NPS translocated mountain goats from Olympic National Park to other ranges throughout several Western States to reduce the population (Houston, Schreiner, and others, 1991). During 1981-89, 407 goats were captured by the NPS and translocated (Houston, Hoffman, and others, 1994, p. 195). An additional 119 mountain goats were legally harvested during sport hunting seasons outside the park and 3 known mountain goats were illegally harvested in the park during 1983-97. The aerial capture and translocation program was halted in 1990 because of human safety concerns associated with aerial capture operations (Houston, Hoffman, and others, 1994). No mountain goats have been translocated from the Olympic Mountains since 1990. Outside the park, mountain goats were not legally harvested between 1997 and 2013. State and Tribal hunting resumed in 2014; three goats were legally harvested between 2014 and July 2016 (R. Harris, Washington Department of Fish and Wildlife, written commun., 2016).

Beginning with the first comprehensive survey conducted in 1983, the mountain goat population has been estimated in the Olympic Mountains every 3-7 years to assess population status and responses to past management actions. The second survey, conducted in July 1990 following the cessation of the NPS capture and translocation program, produced an estimate of $389 \pm 106$ (SE) goats (Houston, Moorhead, and others, 1991). Subsequent surveys were conducted in 1994, 1997, 2004, and 2011 during a period in which no goats were translocated by NPS managers. In this report, we present results from a 2016 survey, which was the seventh survey conducted since 1983, and estimate patterns of population growth since 2004 . 


\section{Study Area and Methods}

The survey encompassed high-elevation mountain goat habitat throughout the Olympic Mountains, of which about 87 percent is in Olympic National Park, and 13 percent is in the adjoining Olympic National Forest (fig. 1). The Olympic Mountains rise abruptly from the coastal plains and foothills of the Olympic Peninsula, culminating in Mount Olympus, the highest peak at an elevation of $2,430 \mathrm{~m}$, and 37 other major peaks at elevations exceeding 2,130 m, all within about $50 \mathrm{~km}$ of the Pacific Ocean, Strait of Juan de Fuca or Puget Sound. The Olympic Mountains are noted for steep gradients in elevation, vegetation, and precipitation within a context of highly convoluted topography and landforms (Tabor, 1987; Henderson and others, 1989).

The western slopes of the Olympic Mountains, which bear the brunt of the prevailing Pacific storms, have the wettest climate in the conterminous United States, generating highly variable snow conditions from year to year. During 2016, snow water equivalent (SWE) measured on April 1 was 108 percent of the 30-year normal (1981-2010). A much warmer than normal spring resulted in a rapid warming and decreasing snowpack. By May 1, the snowpack at measurement sites ranged from 15 to 94 percent of normal depending on aspect. The snow melt-out date at a snowpack reference site (Waterhole SNOTEL, Hurricane Ridge) was 21 days earlier than average. The result was that most steep terrain was largely free of snow in July when the survey was conducted. These conditions contrasted sharply with snow conditions during the previous mountain goat survey (2011), when SWE was about 167 percent of the 30-year normal (1971-2000) on April 1, 225 percent of normal on May 1, and the documented melt-out date was 30 days later than average.

\section{Sampling}

The sampling frame encompassed 60,218 ha comprising all lands free of glacial ice at elevations above $1,520 \mathrm{~m}(5,000 \mathrm{ft})$ as well as areas of suitable mountain goat habitat at elevations between 1,425 and 1,520 $\mathrm{m}$ (fig. 2). We defined suitable habitat as areas where escape terrain comprised at least 50 percent of the elevational band between 1,425 and 1,520 m. We defined escape terrain as any area less than $111 \mathrm{~m}$ from any $25 \times 25-\mathrm{m}(0.0625 \mathrm{ha})$ raster cell classified as rock and with slope greater than 33 percent (Olympic National Park Geographic Information System; Pacific Meridian Resources, 1996). We selected the 111-m threshold because 90 percent of all locations of 11 Global Positioning System (GPS)-collared mountain goats that we tracked during 2005-08 (Jenkins and others, 2011) were within $111 \mathrm{~m}$ from escape cover when they were at elevations below 1,520 during the July sampling window. The 50-percent classification was subjectively selected based on cost and logistical considerations to minimize survey effort over relatively large areas of low-quality habitats. With two exceptions, the 2016 sampling frame was the same frame as that used in 2011 (Jenkins and others, 2012). The exceptions were a minor adjustment to the Klahhane survey unit and the inclusion of the Mount Washington survey unit in 2016, which was excluded in 2011 for logistical reasons. 


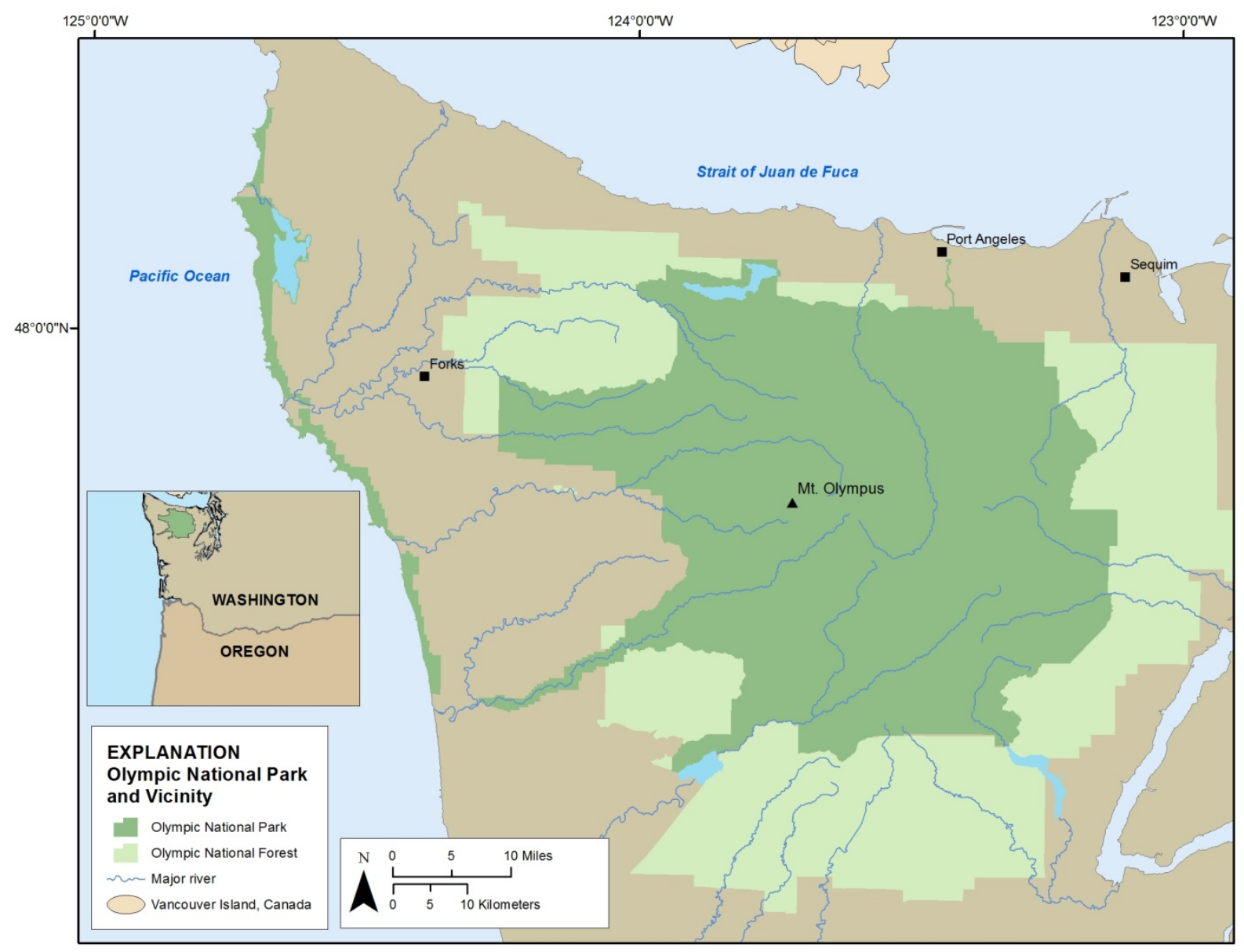

Figure 1. Map showing location of study area in Olympic National Park and Olympic National Forest, northwestern Washington. 


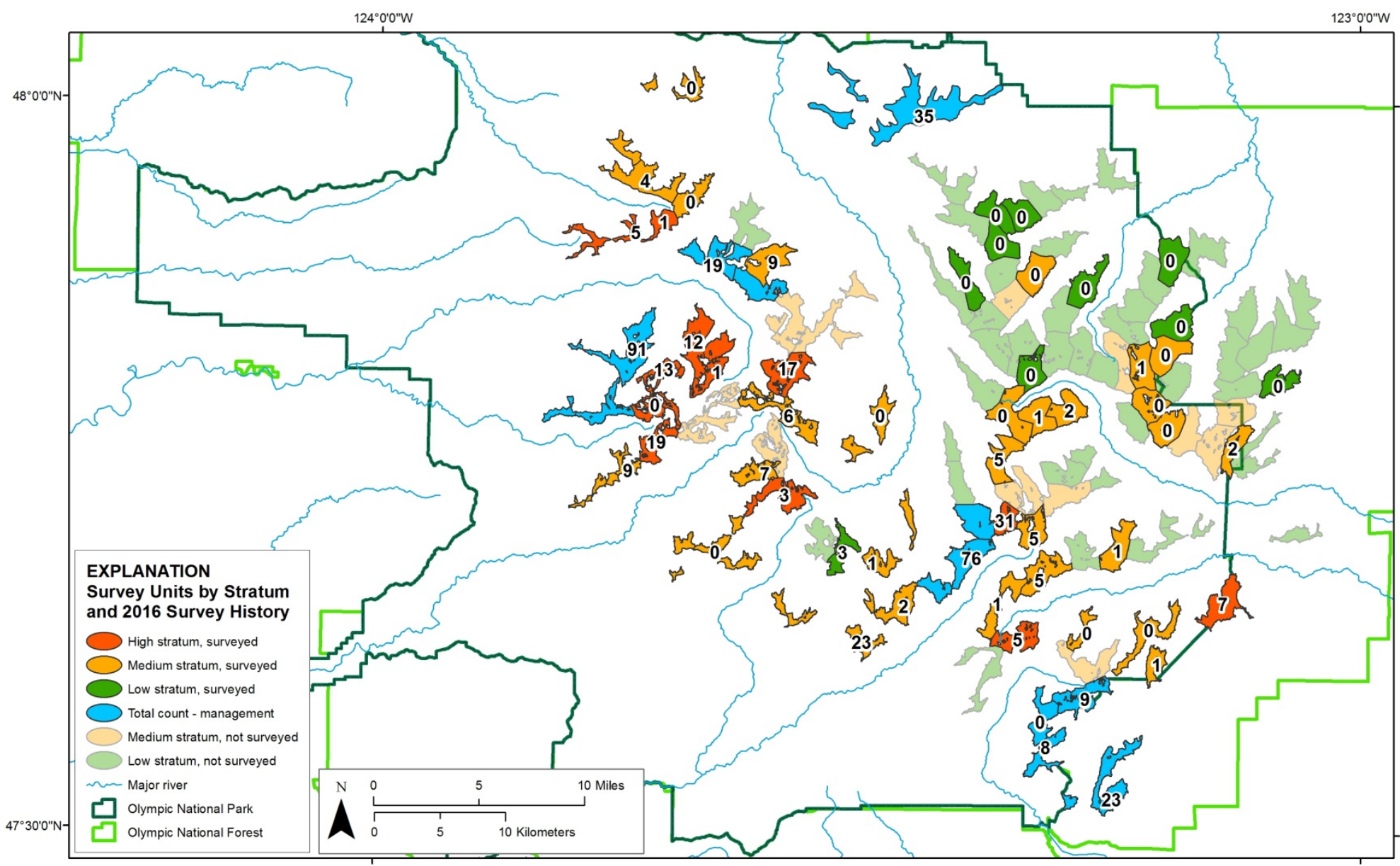

Figure 2. Map showing sampling strata, units surveyed, and number of mountain goats counted during mountain goat surveys in the Olympic Mountains, northwestern Washington, July 13-24, 2016. Total counts and number of kids (young of the year) are presented in appendix 3. 
The sampling frame comprised a total of 109 individual sampling units (fig. 2). Sampling units were selected for the survey based on special management considerations and stratified random sampling methods (Cochran, 1977). As in years past, we assigned each of the survey units to one of four survey strata prior to the surveys. These strata included total count areas (TCAs), and low-density, medium-density, and high-density strata. Total count areas were areas of special management interest, all of which were surveyed. Survey units other than TCAs were assigned to mountain goat density strata based on results of past mountain goat surveys, recent observations of park staff, and visitor reports. With the exception of the TCAs, which were more variable in size, high-, medium- and low-density units ranged in size from 220 to 712 ha. After allotting survey time for all TCA units, we allocated the remaining survey effort among high-, medium-, and low-density strata using standard optimal allocation methods (Cochran, 1977) based on sampling variances reported within each stratum in 2011 (Jenkins and others, 2012). The strata were defined as follows:

I. Total Count Areas (TCAs): We identified eight TCAs that were surveyed in their entirety. Four TCAs were of particular interest to the NPS because they have been included in every survey since 1990. These include survey units on Klahhane Ridge, Mount Olympus, Mount Carrie, and Chimney/Chrystal Peaks (fig. 2). Four additional TCAs were in the Olympic National Forest where hunting seasons are managed by WDFW. Collectively, these eight survey units comprised a total of 8,232 ha or about 14 percent of the sampling frame.

II. Known or suspected high-density areas: Units were assigned to this stratum if we expected to find 10 or more mountain goats per unit based on previous surveys and field observations. We assigned 12 survey units in the high-density stratum, encompassing 5,534 ha and about 9 percent of the sampling frame (fig. 2). We surveyed all units in the high-density stratum.

III. Known or suspected medium-density areas: Units were assigned to this stratum if we expected 1-9 mountain goats inhabiting the survey unit. The medium-density stratum consisted of 42 survey units comprising 21,966 ha (about 36 percent of the sampling frame) (fig. 2). We randomly selected 29 survey units for survey in this stratum.

IV. Known or suspected low-density areas: Units were assigned to this stratum if we expected no mountain goats. The low-density stratum consisted of 47 survey units comprising 24,486 ha or about 41 percent of the sampling frame (fig. 2). We randomly selected 10 survey units for survey in this stratum. 


\section{Aerial Surveys}

Aerial survey procedures were similar to those used in previous surveys (Houston and others, 1986; Houston, Moorhead, and others, 1991; Happe and others, 2005; Rice and others, 2009). We surveyed during mid- to late July, targeting the seasonal window after mountain goats have moved to higher elevations for summer (Rice, 2008; Jenkins and others, 2011), but before hot mid-summer temperatures present operational difficulties for flying at high elevations. Most surveys were conducted between dawn and about 10:30 a.m. PDT by a pilot and three-person crew aboard a Bell 206 B3 helicopter. The pilot's primary responsibility was to safely fly the aircraft, but the pilot also reported observations. We counted mountain goats in the selected survey units by flying multiple contours about $100 \mathrm{~m}$ from the terrain (that is, above flat terrain or horizontally away from vertical terrain) at elevations vertically spaced 90-150 m apart. Flight speed was maintained between 56 and $72 \mathrm{~km} / \mathrm{h}(35$ and 45 $\mathrm{mi} / \mathrm{h}$ ). Low elevations of each unit were flown first and then the helicopter progressively worked upslope until the entire unit was searched. The implicit assumption is that whereas some mountain goats may have been missed because of non-detection, 100 percent of each survey unit was effectively searched. We used a GPS unit aboard the helicopter during all surveys to assist with navigation, to map flight paths, and to record the approximate locations of mountain goats and other wildlife seen during the surveys.

We recorded conditions related to each helicopter flight, survey unit, and group of mountain goats observed. For each flight, we recorded the names of crew members and various flight descriptors (times and locations of takeoffs and landings). We recorded times at the start and end of each unit surveyed and several environmental conditions, including cloud cover, wind strength, precipitation level, and temperature. Upon observing a group of mountain goats, observers recorded the total number of mountain goats, number of young of the year (kids), and the following covariates: (1) the percentage of vegetation cover capable of obscuring a mountain goat within a 10 -m buffer around the group $(0,1-$ $25,26-50,51-75$, or 76-100 percent), and (2) whether terrain obstruction was present within a $10-\mathrm{m}$ buffer around the group at the moment it was first observed. We defined terrain obstruction as any landform capable of obscuring a mountain goat from the air. The group size, vegetation cover, and terrain obstruction covariates were used to estimate group-specific detection probabilities for bias correction (Rice and others, 2009).

We also recorded whether each observed group was in the survey area at elevations below 1,520 $\mathrm{m}$ and whether the group was below, level with, or above the helicopter flight line. These last two pieces of information were recorded so that we could estimate population abundance for sampling frames defined for the 2011 and 2016 surveys (that is, including suitable habitat at elevations between 1,425 and $1,520 \mathrm{~m}$ ) and for the more restricted sampling frame used prior to 2011 (that is, lands at elevations above $1,520 \mathrm{~m})$. 


\section{Population Abundance}

We estimated mountain goat abundance using the sightability modeling approach developed by Samuel and others (1987) and Steinhorst and Samuel (1989). This approach combines counts of animals, or groups of animals, in a set of randomly sampled survey units with a model for their probability of detection. For a stratified random sample of survey units, the estimate of population size $(\hat{\tau})$ is given by:

$$
\hat{\tau}=\sum \sum \sum\left(\frac{N_{h}}{n_{h}} \hat{\theta}_{h, i, j} Y_{h, i, j}\right)
$$

where the sums are over strata $(h)$, sampled survey units $(i)$, and observed groups $(j) ; n_{h}$ and $N_{h}$ are, respectively, the number of stratum $h$ plots in the sample and in the population; the $\hat{\theta}$ 's are estimated sightability correction factors associated with each observed group (that is, the inverse of each group's detection probability); and $Y_{h, i, j}$ gives the number of animals in the $j^{\text {th }}$ observed group (in the $i^{\text {th }}$ survey unit in stratum $h$ ).

We estimated sightability correction factors for each observed group using model-averaged regression coefficients and their unconditional variance covariance matrix from Rice and others (2009), along with formulas from Steinhorst and Samuel (1989). Specifically, Rice and others (2009) used sighting data from 205 sightability trials to model the probability of detection for each mountain goat group $(j), P_{\text {detect }, j}$, as a function of group size (GroupSize, $\left.{ }_{j}\right)$, percent vegetative cover $(\%$ Veg,j), and terrain obstruction (Terrain).

$$
P_{\text {detec }, j}=\frac{e^{\left(\beta_{1}+\beta_{2}{ }^{*} \text { GroupSize }, j+\beta_{3}{ }^{*} \text { Terrain }, j+\beta_{4} \% \text { Veg }, j\right)}}{1+e^{\left(\beta_{1}+\beta_{2}{ }^{*} \text { GroupSize }, j+\beta_{3}{ }^{*} \text { Terrain }, j+\beta_{4}{ }^{*} \% \text { Veg }, j\right)}}=\frac{e^{\left(x_{j}^{\prime} \beta\right)}}{1+e^{\left(x_{j}^{\prime} \beta\right)}}
$$

The estimated regression coefficients ( $\widehat{\beta}$; Rice and others, 2009, p. 474) and their estimated unconditional variance/covariance matrix, $\hat{\Sigma}$ (Rice and others, 2009, p. 474), were then used to estimate the sightability correction factors using the following equation from Steinhorst and Samuel (1989):

$$
\hat{\theta}_{h, i, j}=1+e^{\left(-x_{j}^{\prime} \widehat{\boldsymbol{\beta}}-\frac{x_{j} \widehat{\Sigma} x_{j}^{\prime}}{2}\right)}
$$

Three random processes create uncertainty in the estimated abundance $(\hat{\tau}):(1)$ the random sampling of survey units; (2) random detection (and failed detection) of independent groups in surveyed units; and (3) variation in estimation of parameters used to model sightability. Wong (1996) developed consistent (asymptotically unbiased) estimators of each of these variance components. We estimated $\hat{\tau}$ based on the Steinhorst and Samuel (1989) estimator (eq. 1), and $\operatorname{Var}(\hat{\tau})$ using equations from Wong (1996) as applied in R SightabilityModel package (R Development Core Team, 2011; Fieberg, 2012).

To place the 2004 to 2016 population estimates in historical context, we computed minimum population indices from all surveys conducted from 1983 to 2016. Minimum population indices were based on raw counts of mountain goats without any adjustment for aerial detection biases. To maintain consistency among years, we computed population indices based on survey area boundaries used prior to 2011. We computed population indices based on stratified random sampling computational methods described by Norton-Griffiths (1978) and used by Houston and others (1986) and Houston, Moorhead, and others, 1991). Standard errors of the minimum population indices account for sampling variability only, in contrast to standard errors of the population estimates, which account for sampling variation, random detection, and sightability model estimation. Because indices do not explicitly account for animals present but not seen during surveys, any comparison of indices implicitly assumes that sightability of mountain goats remained constant between surveys. 


\section{Population Trends}

We computed population trends and rates of population increase from surveys conducted in 2004, 2011, and 2016. The 2004 estimate was derived retroactively by applying the detection bias model developed in subsequent years (Rice and others, 2009). Because we adjusted survey boundaries between the 2004 and 2011 surveys, we estimated population growth based on consistent survey boundaries used prior to 2011. That is, all observations of mountain goats from the new survey areas added in 2011 (elevations between 1,425 and 1,520 m) were omitted from the 2011 and 2016 datasets. Because we did not conduct surveys in the Mount Washington survey unit in 2011, we also substituted survey results for that unit from a survey conducted by WDFW partners in 2012. We recognize that there may have been some population growth in the Mount Washington unit between 2011 and 2012 or movement in or out of the unit in the intervening period, but we concluded that adding these data provided a more representative estimate for 2011 and a more valid comparison of population trend across years. We estimated the instantaneous rate of exponential population growth $(r)$ and the average finite rate of growth $\left(\lambda=\mathrm{e}^{r}\right)$ necessary to cause the observed changes in estimated abundance from 2004 to 2016, based on the difference of the log-transformed abundance estimates (Caughley, 1977, p. 51). Because we used the same sightability model to estimate abundance of mountain goats in 2004, 2011, and 2016, we accounted for covariance between years by estimating variance of the population growth rate using the R SightabilityModel package (Fieberg, 2012). We used a two-tailed $z$-test to determine whether or not two estimates of abundance differed statistically from a null hypothesis of zero change (Thompson and others, 1998).

\section{Results}

\section{Aerial Surveys}

Mountain goats were surveyed during six mornings from July 13 to July 24, 2016, in 59 survey units totaling 33,391 ha (table 1). This sampling effort was roughly 40 percent greater than the area surveyed in either 2004 or 2011 (39-41 survey units comprising 23,458-24,524 ha were surveyed in the previous two surveys; Happe and others, 2005; Jenkins and others, 2012). A total of 13 flights were conducted by NPS and 2 flights were conducted by WDFW personnel (appendix 1). Total flight time was about 31 hours and 47 minutes. NPS flights, including travel between survey units and fueling locations, totaled about 26 hours and 17 minutes, and WDFW flights totaled another 5 hours and 30 minutes. On several days, cloud cover interfered with survey efforts. We discontinued surveys in five survey units because of deteriorating weather. All five count units were resurveyed at a later date (appendix 2). A total of 23 hours and 17 minutes were spent actually surveying (that is, disregarding transit times). Two hours were spent on surveys that were omitted because of bad weather, leaving a total of about 21 hours and 17 minutes spent on usable surveys. Survey intensity averaged $3.9 \mathrm{~min} / \mathrm{km}^{2}$ across all surveyed units, ranging from 2.35 to $5.28 \mathrm{~min} / \mathrm{km}^{2}$ in the low and high-density strata, respectively (table 2). Differences in survey intensity among survey units and strata indicated variation in habitat complexity and the time required to count mountain goats and record observations, rather than any variation in our flight patterns. Detailed summaries of all individual flights and survey conditions are provided in appendixes 1 and 2, respectively. 
Table 1. Mountain goat survey characteristics and raw counts of mountain goats in eight total count areas, and in high-, medium-, and low-density strata, Olympic Mountains, northwestern Washington, July 13-24, 2016.

[ha, hectare; min, minute; hr, hour; $\mathrm{min} / \mathrm{km}^{2}$, minute per square kilometer. Totals or averages are reported for each column depending on the quantity reported. ]

\begin{tabular}{lcccccccc}
\hline \multicolumn{1}{c}{ Stratum } & $\begin{array}{c}\text { Area } \\
\text { (ha) }\end{array}$ & $\begin{array}{c}\text { Number } \\
\text { of units }\end{array}$ & $\begin{array}{c}\text { Area } \\
\text { sampled } \\
\text { (ha) }\end{array}$ & $\begin{array}{c}\text { Number } \\
\text { of } \\
\text { survey } \\
\text { units } \\
\text { sampled }\end{array}$ & $\begin{array}{c}\text { Percentage } \\
\text { of stratum } \\
\text { surveyed }\end{array}$ & $\begin{array}{c}\text { Survey } \\
\text { time } \\
\text { (hr) }\end{array}$ & $\begin{array}{c}\text { Survey } \\
\text { intensity } \\
\text { (min/km²) }\end{array}$ & $\begin{array}{c}\text { Number of } \\
\text { goats } \\
\text { observed }\end{array}$ \\
\hline Total count areas & 8,232 & 8 & 8,232 & 8 & 100 & 6.9 & 4.23 & 221 \\
High density & 5,534 & 12 & 5,534 & 12 & 100 & 4.3 & 5.28 & 114 \\
Medium density & 21,966 & 42 & 14,782 & 29 & 67 & 8.1 & 3.72 & 85 \\
Low density & 24,486 & 47 & 4,843 & 10 & 20 & 1.8 & 2.35 & 3 \\
\hline Total & 60,218 & 109 & 33,391 & 59 & & 21.2 & & 463 \\
\hline Average & & & & & 55 & & 3.9 & \\
\hline
\end{tabular}

Table 2. Population estimates of mountain goats, associated components of variance, standard errors, and 95percent confidence intervals in the Olympic Mountains survey area, northwestern Washington, 2004-2016.

[All numbers in table are number of mountain goats, except as otherwise noted. For comparison among years, estimates in 2016 are computed for two survey unit definitions: (1) the expanded survey unit boundaries, which included suitable habitats at elevations above 1,425 meters (m), and (2) the original survey unit boundaries including lands at elevations above 1,520 m. Variance component: Variance components as defined by Steinhorst and Samuel (1989) were computed following Wong (1996). Standard error: Computed as square root of total variance. NAVD 88, North American Vertical Datum of 1988]

\begin{tabular}{llllcrlrl}
\hline & $\begin{array}{c}\text { Survey } \\
\text { boundary } \\
\text { definition } \\
\text { (meters above } \\
\text { NAVD 88) }\end{array}$ & $\begin{array}{l}\text { Estimate } \\
\text { (Number of } \\
\text { goats) }\end{array}$ & Total & Sampling & Detection & Modeling & $\begin{array}{c}\text { Standard } \\
\text { error }\end{array}$ & $\begin{array}{c}\text { 95-percent } \\
\text { confidence } \\
\text { interval }\end{array}$ \\
\hline 2016 & $>1,425$ & 623 & 1,846 & 771 & 424 & 651 & 43 & $561-741$ \\
\hline 2016 & $>1,520$ & 584 & 1504 & 568 & 381 & 555 & 39 & $528-689$ \\
2011 & $>1,520$ & 350 & 1,831 & 1,049 & 441 & 341 & 43 & $294-479$ \\
2004 & $>1,520$ & 230 & 387 & 137 & 168 & 82 & 20 & $205-293$ \\
\hline
\end{tabular}




\section{Population Abundance}

A total of 463 mountain goats were counted in the four strata (table 1, fig. 2, additional detail is provided in appendix 3). The estimated population of mountain goats in the Olympic Mountains survey area corrected for detection bias was $623 \pm 43$ (SE) at the time of the survey (table 2). The total variance of the population estimate, $\operatorname{Var}(\hat{\tau})$, was 1,846 , which accounts for variance associated with random sampling of survey units ( $\operatorname{Var}_{\text {sampling }}=771$ or 42 percent of the total), random detections of independent groups ( $\operatorname{Var}_{\text {detection }}=424$ or 23 percent of total), and uncertainty in model estimation ( Var $_{\text {model }}=651$ or 35 percent of total). The 95-percent confidence interval ranged from 561 to 741 mountain goats. Strictly interpreted, the confidence interval of the estimate implies that if the exact same mountain goat survey were replicated many times, 95 percent of the resulting confidence intervals would include the true mean. Informally, the confidence interval often is considered the range in which we would expect to find the true population size if it were known (Mills, 2013, p. 18).

Minimum population indices based on unadjusted counts of mountain goats in the Olympic Mountains ranged from a high of $764 \pm 116$ (SE) in 1983, to a low of $181 \pm 15$ (SE) in 1997 several years following the cessation of experimental removals (fig. 3). The population index increased from about $191 \pm 10$ (SE) in 2004 to about $516 \pm 27$ (SE) in 2011. Differences between the estimated abundance and minimum population index each year represent the estimated undercounting bias associated with using the uncorrected raw counts of mountain goats.

\section{Population Trends}

Population estimates corrected for detection biases and adjusted for comparable survey boundaries were $230 \pm 20$ (SE) mountain goats in 2004, $350 \pm 43$ (SE) mountain goats in 2011, and 584 \pm 39 (SE) mountain goats in 2016 (table 2, fig. 3). Compared with the overall abundance estimate of 623 mountain goats, the estimate of 584 mountain goats reported here corresponds with the more restricted survey boundaries used in previous years. The estimated population in the expanded survey area was about 7 percent greater than in the previous survey area, representing mountain goats observed in the newly added area at elevations between 1,425 and 1,520 $\mathrm{m}$.

Based on population estimates of mountain goats in comparable survey boundaries, mountain goat abundance was significantly greater in 2016 than in $2011(z=4.63, P<0.01)$. The $z$-statistic indicated that a difference in population estimates of the observed magnitude (or greater) would occur less than 1 percent of the time if the null hypothesis of equal population size was true. The estimated population of mountain goats increased at an instantaneous rate $(r)$ of $0.06 \pm 0.02$ (SE) between 2004 and 2011, $0.10 \pm 0.02$ (SE) between 2011 and 2016, and at an overall rate of $0.08 \pm 0.01$ (SE) for the combined period of 2004-16. These instantaneous rates convert to average annual finite rates of growth approximating 6 percent annually from 2004 to 2011, 11 percent annually from 2011 to 2016, and 8 percent annually over the combined 12 -year period (that is, $\lambda=1.06,1.11$, and 1.08, respectively). 


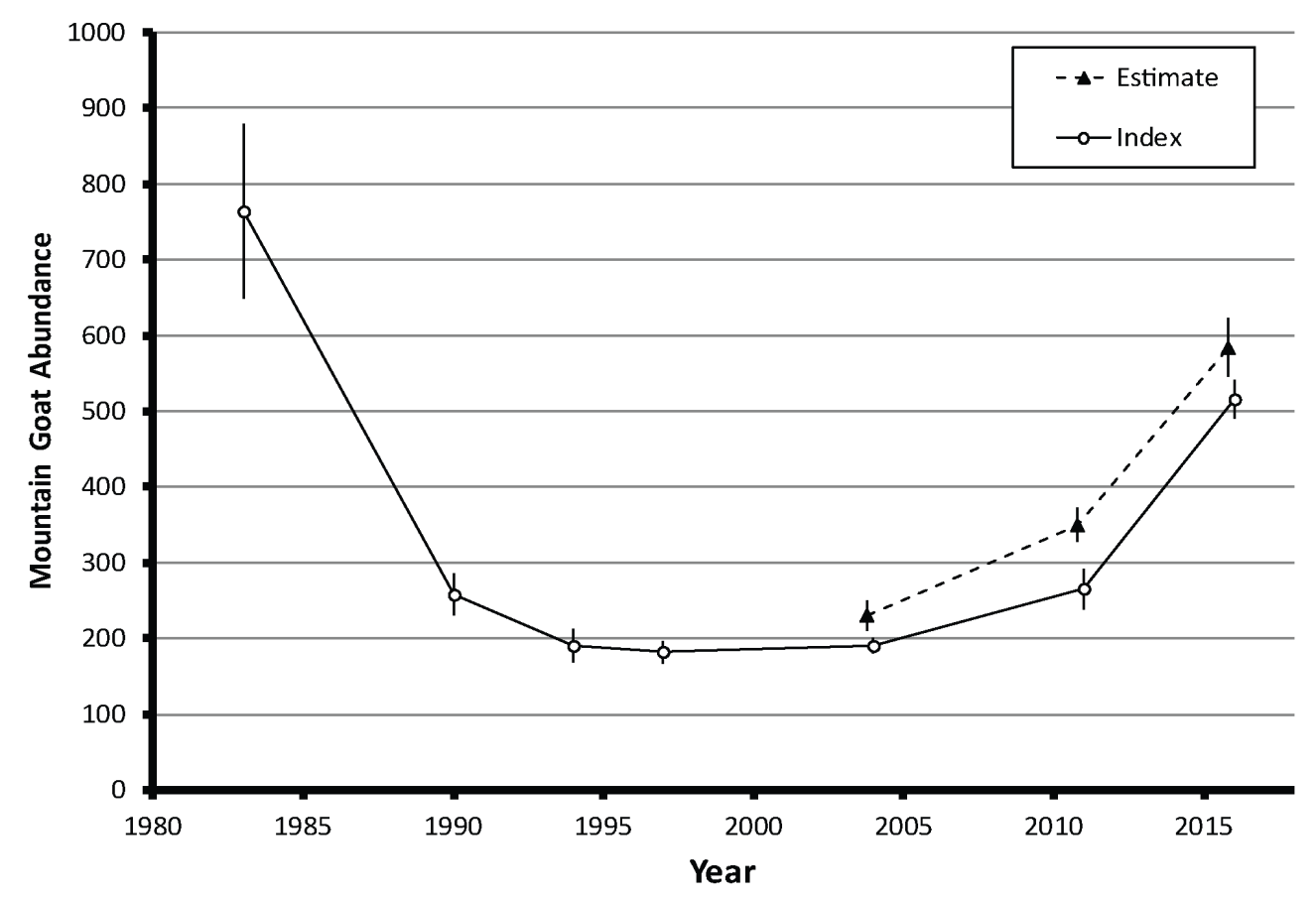

Figure 3. Graph showing trends in the minimum population index and estimated population abundance ( \pm standard error) of mountain goats in the Olympic Mountains, northwestern Washington, 1983-2016. All estimates correspond with survey unit boundaries at elevation contours above 1,520 m and included the Mount Washington survey unit.

\section{Discussion}

The mountain goat population in the Olympic Mountains, which remained at relatively low numbers during the 1990s and began increasing after 2004 (Jenkins and others, 2012), continued to increase between 2011 and 2016. The observed exponential rate of increase, $r$, measured between 2004 and $2016(0.08 \pm 0.01$ [SE]) was less than but comparable (based on the SE) to that measured for the Klahhane Ridge subpopulation during its documented increase in the 1960s and 1970s (about 0.09; Houston and Stevens, 1988).

Comparison of population growth rates from 2011 to $2016(r=0.10)$ compared to 2004-11 $(r=0.06)$ suggested that the rate of population increase may have accelerated after 2011. We caution, however, that poor counting conditions may have resulted in a low population estimate in 2011. Such an underestimation would result in an underestimation of actual population growth from 2004 to 2011 and an overestimation of population growth after 2011. The 2011 surveys followed one of the deepest snow years and latest season snow melts on record in the Olympic Mountains (Jenkins and others, 2012). In Jenkins and others (2012), we speculated that deep snow may have hindered the seasonal movement of mountain goats to high-elevation survey areas during 2011, or that the prevailing white background of snow may have resulted in greater than average detection biases. We cannot, however, rule out the alternative possibility that severe winter and spring conditions in early 2011 promoted a high level of over-winter mortality (White and others, 2011) also contributing to the low population estimate. 
In contrast to conditions that raised uncertainties in the interpretation of 2011 surveys, optimal survey conditions, funding, and interagency cooperation all contributed to a successful survey in 2016. Snowfall during winter 2015-16 was approximately normal, but early snow melt promoted optimal phenology and forage conditions during the survey period. As evidence that mountain goats were distributed at higher elevations in 2016 than in 2011, we found only 7 percent of observations in the lower elevations of the survey area (between 1,425 and 1,520 m) during 2016, compared to 14 percent of observations in 2011 (Jenkins and others, 2012). Furthermore, because of optimal funding levels, survey logistics, and participation of WDFW biologists, we surveyed the largest proportion of goat habitat in 2016 (55 percent) than in any prior survey, contributing to relatively high survey precision.

Our current estimate of population growth from 2004 to $2011(r=0.06)$ was greater than we estimated in a previous report based on a smaller dataset without the Mount Washington unit $(r=0.05$; Jenkins and others, 2012). The difference in estimated rates of population growth is owing to the inclusion of the Mount Washington unit, where counts increased from 12 to 33 between 2004 and 2012. The number of mountain goats in the Mount Washington unit possibly increased from 2011 and 2012, consistent with the general population trends, which may have contributed to a slight overestimation in the 2004-11 rate of population growth. We suspect that because of this potential bias, the true rate of population growth for the entire population from 2004 to 2011 likely is between the previous and current estimates.

The mountain goat population in the Olympic Mountains has sustained growth for more than a decade. Given uncertainties in the 2011 population estimate, the rate of population growth measured from 2004 to $2011(r=0.08)$ likely is the best indication of near future trends. Over the next 5 years, if trends were to remain constant in the absence of density-dependent population responses or management intervention, we would expect the current population of about 623 mountain goats to increase by as much as 45 percent. Any extrapolation past that horizon is clouded by distinct possibilities that density-dependent demographic responses will begin to regulate population growth as was evident during the last population high mark (Houston and Stevens, 1988).

\section{Acknowledgments}

This effort was funded principally by a National Park Service Natural Resources Preservation Program. We would like to thank the Washington Department of Fish and Wildlife (WDFW) for providing additional resources and, specifically, Rich Harris, Cliff Rice, Brian Murphie, and Sara Kindschuh for conducting WDFW surveys. We thank the U.S. Forest Service, Olympic National Forest, for providing the necessary review and permissions to survey over wilderness; and Todd Rankin, Stephanie Frey, and the staff at the Emergency Operations Center and Dispatch Office at Olympic National Park for their help in aviation planning and communications during the surveys. Trevor Williams and Leah Brown were a huge help managing the helispots and assisting with helicopter operations. We are grateful to Rob Olmstead and Jess Hagerman (Northwest Helicopters) for safely piloting all surveys. We thank Cliff Rice (WDFW) and John Fieberg (University of Minnesota) for their long-term collaboration in developing and analyzing mountain goat sightability biases. We appreciate the lasting contributions of Doug Houston, Bruce Moorhead, Rich Olson, and Roger Hoffman at Olympic National Park, who established the mountain goat population survey design and produced the earlier population estimates in the Olympic Mountains. This manuscript was improved by helpful comments provided by two anonymous reviewers. 


\section{References Cited}

Caughley, G., 1977, Analysis of vertebrate populations: London, Wiley, 234 p.

Cochran, W.G., 1977, Sampling techniques, 3rd ed.: New York, Wiley, 428 p.

Fieberg, J., 2012, Estimating population abundance using sightability models - R sightability model package: Journal of Statistical Software, v. 59, p. 1-20.

Happe, P.J., Jenkins, K.J., Beirne, K.F., Albright, J.W., Baccus, W.T., and Olson, R.W., 2005, Mountain goat census in the Olympic Mountain Range, July 2004: Port Angeles, Washington, National Park Service, Olympic National Park.

Henderson, J.A., Peter, D.H., Lesher, R.D., and Shaw, D.C., 1989, Forested plant associations of the Olympic National Forest: U.S. Forest Service, Pacific Northwest Region R6 Ecological Technical Paper 001-88.

Houston, D.B., Hoffman, R.A., Olson, R.W., and Moorhead, B.B., 1994, Mountain goat management in Olympic National Park, in Houston, D.B., Schreiner, E.G., and Moorhead, B.B., eds., Mountain goats in Olympic National Park-Biology and management of an introduced species: National Park Service Scientific Monograph NPS/NROLYM/NRSM-94/25, p. 190-208.

Houston, D.B., Moorhead, B.B., and Olson, R.W., 1986, An aerial census of mountain goats in the Olympic Mountain Range, Washington: Northwest Science, v. 60, p. 131-136.

Houston, D.B., Moorhead, B.B., and Olson, R.W., 1991, Mountain goat population trends in the Olympic Mountain Range, Washington: Northwest Science, v. 65, p. 212-216.

Houston, D.B., Schreiner, E.G., and Moorhead, B.B., eds., 1994, Mountain goats in Olympic National Park-Biology and management of an introduced species: National Park Service Scientific Monograph NPS/NROLYM/NRSM-94/25.

Houston, D.B., Schreiner, E.G., Moorhead, B.B., and Olson, R.W., 1991, Mountain goat management in Olympic National Park-A progress report: Natural Areas Journal, v. 11, p. 87-92.

Houston, D.B., and Stevens, V., 1988, Resource limitation in mountain goats - A test by experimental cropping: Canadian Journal of Zoology, v. 66, p. 228-238.

Jenkins, K., Beirne, K., Happe, P., Hoffman, R., Rice, C., and Schaberl, J., 2011, Seasonal distribution and aerial surveys of mountain goats in Mount Rainier, North Cascades, and Olympic National Parks, Washington: U.S. Geological Survey Open-File Report 2011-1107, 56 p. (Also available at http://pubs.usgs.gov/of/2011/1107/.)

Jenkins, K.J., Happe, P.J., Beirne, K.F., Hoffman, R.A., Griffin, P.C., Baccus, W.T., and Fieberg, J., 2012, Recent population trends of mountain goats in the Olympic Mountains, Washington: Northwest Science, v. 86, p. 264-275.

Mills, L.S., 2013, Conservation of wildlife populations-Demography, genetics, and management (2d ed.): Chichester, West Sussex, United Kingdom, Wiley-Blackwell.

National Park Service, 1995, Goats in Olympic National Park-Draft environmental impact statement for goat management: Port Angeles, Washington, Olympic National Park.

Norton-Griffiths, M., 1978, Counting animals: Nairobi, Kenya, African Wildlife Leadership

Foundation, Serengeti Ecological Monitoring Programme, Handbook No. 1. 
Pacific Meridian Resources, 1996, Vegetation and landform database development study_Final report: Portland, Oregon, Pacific Meridian Resources.

R Development Core Team, 2011, R-A language and environment for statistical computing: Vienna, Austria, R. Foundation for Statistical Computing, accessed November 21, 2011, at http://www.Rproject.org/.

Rice, C.G., 2008, Seasonal altitudinal movements of mountain goats: Journal of Wildlife Management, v. 72, p. 1,706-1,716.

Rice, C.G., Jenkins, K.J., and Chang, W.Y., 2009, A sightability model for mountain goats: Journal of Wildlife Management, v. 73, p. 468-478.

Samuel, M.D., Garton, E.O., Schlegel, M.W., and Carson, R.G., 1987, Visibility bias during aerial surveys of elk in north-central Idaho: Journal of Wildlife Management, v. 51, p. 622-630.

Steinhorst, K.R., and Samuel, M.D., 1989, Sightability adjustment methods for aerial surveys of wildlife populations: Biometrics. v. 45, p. 415-425.

Tabor, R.W., 1987, Guide to the geology of Olympic National Park: Pacific Northwest Parks and Forest Association, Seattle, Washington, 144 p.

Thompson, W.L., White, G.C., and Gowan, C., 1998, Monitoring vertebrate populations: San Diego, Academic Press.

White, K.S., Pendleton, G. W., Crowley, D., Griese, H. J., Hundertmark, K. J., Mcdonough, T., Nichols, L., Robus, M., Smith, C. A., Schoen, J. W., 2011, Mountain goat survival in coastal Alaska-Effects of age, sex, and climate: Journal of Wildlife Management. v. 75, p.1,731-1,744.

Wong, C., 1996, Population size estimation using the modified Horvitz-Thompson estimator with estimated sighting probabilities: Fort Collins, Colorado, Colorado State University, Ph.D. dissertation. 


\section{Appendix 1. Survey Flight Characteristics during Aerial Mountain Goat Surveys, Olympic Mountains, Northwestern Washington, 2016}

[Survey duration: Total time spent on surveys excluding time spent flying to and among survey units. Navigator/observer: Operated Global Positioning System during surveys. Primary observer: Focused on searching for goats at all times. Secondary observer: Data recorder: recorded all observations and covariate data]

\begin{tabular}{|c|c|c|c|c|c|c|c|c|c|c|c|}
\hline \multirow[b]{2}{*}{$\begin{array}{l}\text { Flight } \\
\text { No. }\end{array}$} & \multirow[b]{2}{*}{ Date } & \multirow[b]{2}{*}{$\begin{array}{c}\text { Departure } \\
\text { time (a.m. } \\
\text { PDT) }\end{array}$} & \multirow[b]{2}{*}{$\begin{array}{l}\text { Departure } \\
\text { location }\end{array}$} & \multirow[b]{2}{*}{$\begin{array}{l}\text { Arrival } \\
\text { Time }\end{array}$} & \multirow[b]{2}{*}{ Arrival location } & \multirow[b]{2}{*}{$\begin{array}{l}\text { Flight duration } \\
\text { (hours:min) }\end{array}$} & \multirow[b]{2}{*}{$\begin{array}{l}\text { Survey duration } \\
\text { (hours:min) }\end{array}$} & \multicolumn{4}{|c|}{ Personnel/seating position } \\
\hline & & & & & & & & $\begin{array}{l}\text { Right front: } \\
\text { Pilot }\end{array}$ & $\begin{array}{l}\text { Left back: } \\
\text { Navigator/ } \\
\text { observer }\end{array}$ & $\begin{array}{l}\text { Left front: } \\
\text { Primary } \\
\text { observer }\end{array}$ & $\begin{array}{c}\text { Right back } \\
\text { Secondary } \\
\text { observer }\end{array}$ \\
\hline ONP0 $1^{1}$ & $7 / 13 / 2016$ & $5: 40$ & Port Angeles & $8: 10$ & Sweets Field & $2: 29$ & $1: 57$ & Olmstead & Beirne & Happe & Baccus \\
\hline ONP02 & $7 / 14 / 2016$ & $5: 20$ & Port Angeles & $7: 18$ & Obstruction & $1: 58$ & $1: 14$ & Olmstead & Beirne & Happe & Baccus \\
\hline ONP03 & $7 / 14 / 2016$ & $7: 37$ & Obstruction & $9: 43$ & Obstruction & $2: 06$ & $1: 38$ & Olmstead & Beirne & Happe & Baccus \\
\hline ONP04 & $7 / 14 / 2016$ & $10: 03$ & Obstruction & $11: 12$ & Sweets Field & $1: 08$ & $0: 30$ & Olmstead & Beirne & Happe & Baccus \\
\hline ONP05 & $7 / 15 / 2016$ & $5: 15$ & Sweets Field & $8: 12$ & Obstruction & $2: 57$ & $2: 22$ & Olmstead & Beirne & Happe & Baccus \\
\hline ONP06 & $7 / 15 / 2016$ & $8: 41$ & Obstruction & $10: 41$ & Sweets Field & $2: 00$ & $1: 38$ & Olmstead & Beirne & Happe & Baccus \\
\hline ONP07 & $7 / 16 / 2016$ & $5: 17$ & Sweets Field & $7: 46$ & Obstruction & $2: 29$ & $1: 59$ & Olmstead & Beirne & Happe & Baccus \\
\hline ONP08 & $7 / 16 / 2016$ & $8: 07$ & Obstruction & $10: 24$ & Sweets Field & $2: 17$ & $1: 58$ & Olmstead & Beirne & Happe & Baccus \\
\hline ONP09 & $7 / 17 / 2013$ & $5: 14$ & Sweets Field & $7: 42$ & Obstruction & $2: 28$ & $1: 52$ & Olmstead & Beirne & Happe & Baccus \\
\hline ONP10 ${ }^{1}$ & $7 / 17 / 2013$ & 8:03 & Obstruction & $9: 15$ & Sweets Field & $1: 12$ & $0: 41$ & Olmstead & Beirne & Happe & Baccus \\
\hline ONP11 & $7 / 24 / 2016$ & $5: 26$ & Obstruction & $6: 59$ & Obstruction & $1: 33$ & $1: 23$ & Olmstead & Beirne & Happe & Baccus \\
\hline ONP12 & $7 / 24 / 2016$ & $7: 26$ & Obstruction & $9: 29$ & Obstruction & $2: 03$ & $1: 33$ & Olmstead & Beirne & Happe & Baccus \\
\hline ONP13 & $7 / 24 / 2016$ & $9: 52$ & Obstruction & $11: 29$ & Shelton Airport & $1: 37$ & $1: 07$ & Olmstead & Beirne & Happe & Baccus \\
\hline W01 & $7 / 14 / 2016$ & $6: 15$ & Olympia & . & Bremerton & . & $1: 53$ & Hagerman & Rice & Harris & Kindschuh \\
\hline $\mathrm{W} 02^{1}$ & $7 / 14 / 2016$ & . & Bremerton & $12: 45$ & Olympia & ${ }^{2} 5: 30$ & $1: 32$ & Hagerman & Rice & Harris & Kindschuh \\
\hline $\begin{array}{c}\text { Total } \\
\text { hours }\end{array}$ & & & & & & $31: 47$ & $23: 17$ & & & & \\
\hline
\end{tabular}

${ }^{1}$ Survey curtailed because of deteriorating weather.

${ }^{2}$ Flight duration calculations include refueling time. Estimated flight hours are 5 hours and 30 minutes for the Washington Department of Fish and Wildlife surveys. 


\section{Appendix 2. Survey Characteristics and Environmental Conditions Measured at the Beginning of Each Unit Surveyed in the Olympic Mountains, Northwestern Washington, 2016}

[Polygons are subunits that are used for data recording and survey planning. Duration of survey in each surveyed unit. Ppt: Precipitation level. At elevation: Elevation at which air temperature was recorded, in feet above North American Vertical Datum of 1988. Light refers to lighting conditions during the survey. High lighting casts shadows whereas flat lighting does not. oC, degrees Celsius; $\mathrm{ft}$, feet; h, hour; min, minute; sec, second; km², square kilometer. No data were recorded during the survey for table cells that are left blank]

\begin{tabular}{|c|c|c|c|c|c|c|c|c|c|c|c|c|c|}
\hline $\begin{array}{l}\text { Flight } \\
\text { No. }\end{array}$ & Date & Unit ID & Polygon ID(s) & $\begin{array}{l}\text { Unit area } \\
\left(\mathrm{km}^{2}\right)\end{array}$ & $\begin{array}{c}\text { Survey } \\
\text { duration } \\
\text { (hh:min:sec) }\end{array}$ & $\begin{array}{c}\text { Survey } \\
\text { intensity } \\
\left(\mathrm{min}: \mathrm{sec} / \mathrm{km}^{2}\right)\end{array}$ & Sky condition & Winds & Ppt & $\begin{array}{l}\text { Cloud } \\
\text { cover } \\
\text { (percent) }\end{array}$ & $\begin{array}{l}\text { Temp } \\
\left({ }^{\circ} \mathrm{C}\right)\end{array}$ & $\begin{array}{c}\text { At } \\
\text { elevation } \\
\text { (ft) }\end{array}$ & Light \\
\hline ONP-01 & $7 / 13 / 2016$ & $143 \mathrm{~W}$ & $143 \mathrm{~W}$ & 2.6 & $0: 15: 10$ & $0: 05: 55$ & clear & calm & none & 0 & 4 & 5,500 & Flat \\
\hline ONP-01 & $7 / 13 / 2016$ & 141 & 141,142 & 3.8 & 0:24:00 & $0: 06: 23$ & clear & calm & none & 0 & & & Flat \\
\hline ONP-01 & $7 / 13 / 2016$ & 129 & 129 & 6.7 & $0: 23: 28$ & 0:03:31 & clear & & & & & & \\
\hline ONP-01 & $7 / 13 / 2016$ & ${ }^{1} 137$ & 139,137 part & $\left({ }^{1}\right)$ & $0: 33: 18$ & $\left({ }^{1}\right)$ & mostly clear- fog & calm & none & 30 & & & Flat \\
\hline ONP-01 & $7 / 13 / 2016$ & 145 & $145,146,147$ & 5.3 & $0: 21: 25$ & 0:04:05 & mostly cloudy & calm & none & 50 & & & Flat \\
\hline ONP-02 & $7 / 14 / 2016$ & 122 & 122 & 4.0 & $0: 14: 46$ & $0: 03: 42$ & clear & light & none & 0 & 7 & 5,000 & Flat \\
\hline ONP-02 & $7 / 14 / 2016$ & $127 \mathrm{~S}$ & $127 \mathrm{~S}$ & 3.5 & 0:19:00 & $0: 05: 30$ & clear & calm & none & 0 & & & Flat \\
\hline ONP-02 & $7 / 14 / 2016$ & 125 & 125,126 & 5.5 & 0:39:59 & $0: 07: 15$ & clear & light & none & 0 & & & \\
\hline ONP-03 & $7 / 14 / 2016$ & 125 & 128 & 9.1 & $0: 43: 28$ & 0:04:46 & clear & calm & none & 0 & 8 & 5,000 & \\
\hline ONP-03 & $7 / 14 / 2016$ & $127 \mathrm{~N}$ & $127 \mathrm{~N}$ & 2.3 & $0: 20: 32$ & 0:08:46 & & & & & & & \\
\hline ONP-03 & $7 / 14 / 2016$ & 130 & 130 & 5.8 & $0: 33: 44$ & 0:05:46 & clear & calm & none & 20 & 7 & 6,000 & High \\
\hline ONP-04 & $7 / 14 / 2016$ & 35 & 35 & 5.6 & $0: 12: 21$ & $0: 02: 13$ & clear & calm & none & 0 & 9 & 5,000 & High \\
\hline ONP-04 & $7 / 14 / 2016$ & 27 & 27 & 5.5 & 0:18:09 & $0: 03: 17$ & clear & calm & none & 0 & 9 & 5,000 & High \\
\hline ONP-05 & $7 / 15 / 2016$ & 119 & $119,120,121$ & 3.8 & $0: 22: 43$ & 0:06:01 & clear & moderate & none & 0 & 8 & 5,000 & Flat \\
\hline ONP-05 & $7 / 15 / 2016$ & 110 & $110,111,112,113,150$ & 6.6 & $0: 18: 54$ & $0: 02: 52$ & clear & light & none & 0 & & & Flat \\
\hline ONP-05 & $7 / 15 / 2016$ & 115 & 115 & 6.1 & $0: 31: 13$ & 0:05:08 & clear & light & none & 0 & 9 & & \\
\hline ONP-05 & $7 / 15 / 2016$ & $116 \mathrm{~W}$ & $116 \mathrm{~W}$ & 3.8 & $0: 14: 52$ & $0: 03: 52$ & clear & light & none & 0 & & & \\
\hline ONP-05 & $7 / 15 / 2016$ & 124 & 124 & 7.0 & $0: 29: 37$ & $0: 04: 15$ & clear & light & none & 0 & & & \\
\hline ONP-05 & $7 / 15 / 2016$ & 131 & 131 & 6.7 & $0: 24: 45$ & 0:03:43 & clear & light & none & 0 & 8 & 6,000 & High \\
\hline ONP-06 & $7 / 15 / 2016$ & 102 & 102 & 5.6 & $0: 15: 37$ & 0:02:48 & clear & light & none & 0 & 8 & 6,000 & \\
\hline ONP-06 & $7 / 15 / 2016$ & 101 & $101,104,107$ & 4.9 & $0: 29: 48$ & 0:06:07 & & & & & & & \\
\hline \multirow[t]{2}{*}{ ONP-06 } & $7 / 15 / 2016$ & 109 & 109 & 3.6 & $0: 12: 42$ & 0:03:30 & clear & light & none & 0 & & & \\
\hline & & & & & & 17 & & & & & & & \\
\hline
\end{tabular}




\begin{tabular}{|c|c|c|c|c|c|c|c|c|c|c|c|c|c|}
\hline $\begin{array}{l}\text { Flight } \\
\text { No. }\end{array}$ & Date & Unit ID & Polygon ID(s) & $\begin{array}{c}\text { Unit area } \\
\left(\mathrm{km}^{2}\right)\end{array}$ & $\begin{array}{c}\text { Survey } \\
\text { duration } \\
\text { (hh:min:sec) }\end{array}$ & $\begin{array}{c}\text { Survey } \\
\text { intensity } \\
\left(\mathrm{min}: \mathrm{sec} / \mathrm{km}^{2}\right)\end{array}$ & Sky condition & Winds & Ppt & $\begin{array}{c}\text { Cloud } \\
\text { cover } \\
\text { (percent) }\end{array}$ & $\begin{array}{l}\text { Temp } \\
\left({ }^{\circ} \mathrm{C}\right)\end{array}$ & $\begin{array}{c}\text { At } \\
\text { elevation } \\
\text { (ft) }\end{array}$ & Light \\
\hline ONP-06 & $7 / 15 / 2016$ & 105 & 105,106 & 5.0 & $0: 13: 33$ & $0: 02: 43$ & clear & light & none & 0 & & & \\
\hline ONP-06 & $7 / 15 / 2016$ & 70 & 70 & 5.1 & $0: 14: 44$ & $0: 02: 53$ & clear & light & none & 0 & & & \\
\hline ONP-06 & $7 / 15 / 2016$ & 49 & 49 & 5.1 & $0: 11: 37$ & $0: 02: 17$ & clear & light & none & 0 & & & \\
\hline ONP-07 & $7 / 16 / 2016$ & 69 & $69,78,103$ & 14.2 & $1: 46: 24$ & $0: 04: 55$ & mostly clear & calm & none & 0 & 9 & 5,000 & Flat \\
\hline ONP-07 & $7 / 16 / 2016$ & $73 \mathrm{~W}$ & $73 \mathrm{~W}$ & 3.0 & $\left({ }^{2}\right)$ & $\left({ }^{2}\right)$ & mostly cloudy & calm & none & 60 & & & Flat \\
\hline ONP-07 & $7 / 16 / 2016$ & $73 \mathrm{E}$ & $73 \mathrm{E}$ & 4.4 & $\left({ }^{2}\right)$ & $\left({ }^{2}\right)$ & & & & & & & \\
\hline ONP-07 & $7 / 16 / 2016$ & 32 & 32 & 4.8 & 0:13:05 & $0: 02: 45$ & mostly clear & calm & none & 0 & 8 & 7,000 & High \\
\hline ONP-08 & $7 / 16 / 2016$ & 137 & 139,137 & 12.4 & 1:15:06 & $\left({ }^{3}\right)$ & clear & calm & none & 0 & 10 & 5,000 & High \\
\hline ONP-08 & $7 / 16 / 2016$ & 138 & 138 & 5.7 & $\left({ }^{2}\right)$ & $\left({ }^{2}\right)$ & clear & calm & none & 10 & 9 & 6,000 & High \\
\hline ONP-08 & $7 / 16 / 2016$ & $143 \mathrm{E}$ & $143 \mathrm{E}$ & 4.0 & $0: 18: 56$ & $0: 04: 41$ & & & & & & & \\
\hline ONP-08 & $7 / 16 / 2016$ & 144 & 144 & 7.1 & 0:24:05 & $0: 03: 25$ & & & & & & & \\
\hline ONP-09 & $7 / 17 / 2013$ & ${ }^{1} 1$ & 3 & $\left({ }^{1}\right)$ & 0:11:55 & $\left({ }^{1}\right)$ & mostly clear & calm & none & 10 & 9 & 5,000 & Flat \\
\hline ONP-09 & $7 / 17 / 2013$ & 54 & 54 & 5.1 & $0: 23: 58$ & $0: 02: 23$ & clear & calm & none & 0 & & & Flat \\
\hline ONP-09 & $7 / 17 / 2013$ & 52 & 52 & 4.9 & $\left({ }^{2}\right)$ & $\left({ }^{2}\right)$ & clear & calm & none & 0 & & & Flat \\
\hline ONP-09 & $7 / 17 / 2013$ & 44 & 44 & 5.3 & 0:32:05 & $0: 02: 52$ & mostly clear & calm & none & & & & High \\
\hline ONP-09 & $7 / 17 / 2013$ & 45 & 45 & 5.9 & $\left({ }^{2}\right)$ & $\left({ }^{2}\right)$ & mostly clear & calm & none & 15 & & & Flat \\
\hline ONP-09 & $7 / 17 / 2013$ & 46 & 46 & 5.8 & 0:10:29 & 0:01:49 & mostly clear & calm & none & 20 & & & Flat \\
\hline ONP-09 & $7 / 17 / 2013$ & 42 & 42 & 6.1 & $0: 10: 56$ & 0:01:48 & mostly clear & calm & none & 10 & & & High \\
\hline ONP-09 & $7 / 17 / 2013$ & 17 & 17 & 4.4 & 0:08:27 & 0:01:55 & mostly clear & calm & none & 15 & & & Flat \\
\hline ONP-09 & $7 / 17 / 2013$ & 16 & 16 & 4.5 & 0:05:55 & 0:01:19 & mostly clear & calm & none & 15 & & & Flat \\
\hline ONP-09 & $7 / 17 / 2013$ & 22 & 22 & 4.9 & $0: 08: 12$ & 0:01:40 & mostly clear & calm & none & & & & High \\
\hline ONP-10 & $7 / 17 / 2013$ & ${ }^{1} 1$ & 4 & $\left({ }^{1}\right)$ & 0:21:04 & $\left({ }^{1}\right)$ & mostly cloudy & & & & 10 & & Flat \\
\hline ONP-10 & $7 / 17 / 2013$ & 117 & 117,118 & 5.0 & $0: 20: 04$ & 0:03:59 & mostly cloudy & light & none & 70 & 11 & 4,000 & Flat \\
\hline ONP-11 & $7 / 24 / 2016$ & 1 & $2,3,4$ & 19.3 & $1: 10: 10$ & $0: 03: 38$ & clear & light & none & 0 & 12 & 6,000 & \\
\hline ONP-11 & $7 / 24 / 2016$ & 24 & 24 & 4.7 & $0: 12: 27$ & $0: 02: 39$ & clear & light & none & 0 & 12 & 6,000 & High \\
\hline ONP-12 & $7 / 24 / 2016$ & 64 & 64 & 4.1 & $0: 15: 50$ & 0:03:50 & clear & light & none & 0 & 12 & 6,000 & High \\
\hline ONP-12 & $7 / 24 / 2016$ & $65 \mathrm{~W}$ & $65 \mathrm{~W}$ & 4.0 & $0: 19: 28$ & $0: 04: 53$ & clear & light & none & 0 & & & High \\
\hline ONP-12 & $7 / 24 / 2016$ & 85 & 85 & 5.4 & $0: 20: 57$ & $0: 03: 53$ & clear & light & none & 0 & & & High \\
\hline ONP-12 & $7 / 24 / 2016$ & 50 & 50 & 5.0 & $0: 17: 51$ & $0: 03: 34$ & clear & light & none & 0 & & & High \\
\hline ONP-12 & $7 / 24 / 2016$ & 48 & 48 & 6.9 & $0: 18: 26$ & $0: 02: 41$ & clear & light & none & 0 & 12 & 7,000 & High \\
\hline
\end{tabular}




\begin{tabular}{|c|c|c|c|c|c|c|c|c|c|c|c|c|c|}
\hline $\begin{array}{l}\text { Flight } \\
\text { No. }\end{array}$ & Date & Unit ID & Polygon ID(s) & $\begin{array}{l}\text { Unit area } \\
\left(\mathrm{km}^{2}\right)\end{array}$ & $\begin{array}{c}\text { Survey } \\
\text { duration } \\
\text { (hh:min:sec) }\end{array}$ & $\begin{array}{c}\text { Survey } \\
\text { intensity } \\
\left(\mathrm{min}: \mathrm{sec} / \mathrm{km}^{2}\right)\end{array}$ & Sky condition & Winds & Ppt & $\begin{array}{c}\text { Cloud } \\
\text { cover } \\
\text { (percent) }\end{array}$ & $\begin{array}{c}\text { Temp } \\
\left({ }^{\circ} \mathrm{C}\right)\end{array}$ & $\begin{array}{c}\text { At } \\
\text { elevation } \\
\text { (ft) }\end{array}$ & Light \\
\hline ONP-13 & $7 / 24 / 2016$ & 98 & 98 & 6.3 & $0: 31: 23$ & 0:05:01 & clear & light & none & 0 & 12 & 5,000 & High \\
\hline ONP-13 & $7 / 24 / 2016$ & 96 & 96 & 5.8 & $0: 21: 30$ & $0: 03: 42$ & clear & light & none & 0 & & & High \\
\hline ONP-13 & $7 / 24 / 2016$ & 97 & 97 & 2.7 & $0: 14: 04$ & 0:05:08 & clear & light & none & 0 & 13 & 5,000 & High \\
\hline W-01 & $7 / 14 / 2016$ & 99 & 100 & 7.2 & $0: 34: 00$ & $0: 04: 43$ & clear & & & & 9 & 4,000 & \\
\hline W-01 & $7 / 14 / 2016$ & 90 & 99 & 0.8 & 0:04:00 & 0:04:50 & clear & & & & 6 & 5,000 & \\
\hline W-01 & $7 / 14 / 2016$ & 90 & 90 & 3.6 & $0: 14: 00$ & $0: 03: 51$ & clear & & & & 4 & 5,500 & \\
\hline W-01 & $7 / 14 / 2016$ & 91 & 91 & 1.7 & 0:05:00 & $0: 02: 55$ & clear & & & & 4 & 6,000 & \\
\hline W-01 & $7 / 14 / 2016$ & 91 & 92 & 2.6 & 0:06:00 & 0:02:19 & clear & & & & 5 & 5,500 & \\
\hline W-01 & $7 / 14 / 2016$ & 93 & 93 & 5.8 & 0:18:00 & 0:03:07 & clear & & & & & & \\
\hline W-01 & $7 / 14 / 2016$ & ${ }^{1} 96$ & 96 & $\left({ }^{1}\right)$ & 0:19:00 & $\left({ }^{1}\right)$ & clear - fog & & & & 5 & 5,500 & \\
\hline W-01 & $7 / 14 / 2016$ & ${ }^{1} 97$ & 97 & $\left({ }^{1}\right)$ & 0:13:00 & $\left({ }^{1}\right)$ & clear - fog & & & & 4 & 5,500 & \\
\hline W-02 & $7 / 14 / 2016$ & ${ }^{1} 98$ & 98 & $\left({ }^{1}\right)$ & $0: 26: 00$ & $\left({ }^{1}\right)$ & clear - fog & & & & 6 & 5,000 & \\
\hline W-02 & $7 / 14 / 2016$ & 95 & 95 & 2.2 & 0:08:00 & 0:03:38 & clear & & & & 6 & 5,500 & \\
\hline W-02 & $7 / 14 / 2016$ & 83 & 83 & 6.0 & 0:18:00 & 0:03:00 & & & & & & & \\
\hline W-02 & $7 / 14 / 2016$ & 82 & 82 & 4.7 & 0:18:00 & 0:03:51 & & & & & & & \\
\hline $\mathrm{W}-02$ & $7 / 14 / 2016$ & $81 \mathrm{E}$ & $81 \mathrm{E}$ & 4.7 & 0:22:00 & 0:04:40 & & & & & 7 & 5,500 & \\
\hline
\end{tabular}

${ }^{1}$ Survey was curtailed because of deteriorating weather. Not all unit was surveyed. Unit was counted later on another flight.

${ }^{2}$ Unit(s) were surveyed with preceding units. Time and intensity values are for the group of units surveyed together.

${ }^{3}$ Unit was surveyed on multiple flights. Survey effort calculations are not valid. 


\section{Appendix 3. Raw Counts of Mountain Goats by Survey Unit, Olympic Mountains, Northwestern Washington, 2016}

[For each unit, the number of mountain goats observed in the part of the survey unit at elevations below 1,520 meters above North American Vertical Datum of 1988 is noted in parentheses. Stratum: TCA, Total Count Area; $\mathrm{H}$, high density; M, medium density; L, low density]

\begin{tabular}{|c|c|c|c|c|c|c|}
\hline Stratum & Unit ID & Unit name & $\begin{array}{c}\text { Number } \\
\text { of } \\
\text { groups }\end{array}$ & Total & Adults & Kids \\
\hline TCA & 1 & Klahhane Total Count & 12 & 35 & 28 & 7 \\
\hline TCA & 69 & Chimney Total Count & 44 & 76 & 63 & 13 \\
\hline TCA & 90 & Sawtooths & 3 & 8 & 6 & 2 \\
\hline TCA & 91 & Gladys/Henderson & 0 & & & \\
\hline TCA & 93 & Mount Skokomish & 4 & 9 & 8 & 1 \\
\hline TCA & 99 & Mount Washington & 3 & 23 & 18 & 5 \\
\hline TCA & 125 & Olympus Total Count & 41 & $91(5)$ & 75 & 16 \\
\hline TCA & 137 & Carrie Total Count & 8 & 19 & 17 & 2 \\
\hline $\mathrm{H}$ & $73 \mathrm{~W}$ & Mount Anderson West & 13 & 31 & 25 & 6 \\
\hline $\mathrm{H}$ & $81 \mathrm{E}$ & Steel East & 3 & 5 & 5 & 0 \\
\hline $\mathrm{H}$ & 98 & The Brothers & 6 & $7(1)$ & 7 & 0 \\
\hline $\mathrm{H}$ & 115 & Seattle & 3 & 3 & 3 & 0 \\
\hline $\mathrm{H}$ & 122 & Paull Creek & 10 & $19(5)$ & 15 & 4 \\
\hline $\mathrm{H}$ & $127 \mathrm{~N}$ & Olympus Summit North & 4 & $13(6)$ & 8 & 5 \\
\hline $\mathrm{H}$ & $127 \mathrm{~S}$ & Olympus Summit South & 0 & & & \\
\hline $\mathrm{H}$ & 129 & Glacier Meadows & 7 & $12(3)$ & 9 & 3 \\
\hline $\mathrm{H}$ & 130 & Mount Mathias & 1 & 1 & 1 & 0 \\
\hline $\mathrm{H}$ & 131 & Mount Childs & 6 & 17 & 15 & 2 \\
\hline $\mathrm{H}$ & 141 & High Divide/Bogaciel & 4 & 5 & 4 & 1 \\
\hline $\mathrm{H}$ & $143 \mathrm{~W}$ & High Divide West & 1 & 1 & 1 & 0 \\
\hline M & 27 & Moose Lake & 0 & & & \\
\hline M & 44 & Mount Deception & 1 & 1 & 1 & 0 \\
\hline M & 45 & Royal Lake & 0 & & & \\
\hline M & 48 & Mount Fromme & 0 & & & \\
\hline M & 49 & Thousand Acre Meadow & 1 & 1 & 1 & 0 \\
\hline M & 50 & Wellesley Peak & 1 & 2 & 2 & 0 \\
\hline M & 52 & Mount Mystery & 0 & & & \\
\hline M & 54 & Sunnybrook Meadows & 0 & & & \\
\hline M & 65 & Constance West & 1 & 2 & 2 & 0 \\
\hline M & 70 & Sentinel & 1 & 5 & 3 & 2 \\
\hline M & $73 \mathrm{E}$ & Mount Anderson East & 5 & 5 & 5 & 0 \\
\hline M & 82 & Hart Lake & 1 & 1 & 1 & 0 \\
\hline M & 83 & LaCrosse & 1 & 5 & 4 & 1 \\
\hline M & 85 & Mount Elk Lick & 1 & 1 & 1 & 0 \\
\hline
\end{tabular}




\begin{tabular}{|c|c|c|c|c|c|c|}
\hline Stratum & Unit ID & Unit name & $\begin{array}{c}\text { Number } \\
\text { of } \\
\text { groups }\end{array}$ & Total & Adults & Kids \\
\hline $\mathrm{M}$ & 95 & Mount Hopper & 0 & & & \\
\hline M & 96 & Lena Lake & 0 & & & \\
\hline M & 97 & Mount Bretherton & 1 & 1 & 1 & 0 \\
\hline M & 101 & Muncaster & 5 & $23(4)$ & 18 & 5 \\
\hline M & 102 & Rustler & 2 & 2 & 2 & 0 \\
\hline M & 105 & Delabarre & 1 & 1 & 1 & 0 \\
\hline M & 110 & Muncaster & 0 & & & \\
\hline M & 117 & Mount Dana. & 0 & & & \\
\hline M & $116 \mathrm{~W}$ & Mount Queets West & 2 & 7 & 5 & 2 \\
\hline M & 119 & Valhallas & 8 & $9(1)$ & 9 & 0 \\
\hline M & 124 & Mount Barnes & 3 & $6(2)$ & 5 & 1 \\
\hline M & 138 & Long Creek & 4 & 9 & 7 & 2 \\
\hline M & $143 \mathrm{E}$ & High Divide East & 0 & & & \\
\hline M & 144 & Appleton & 2 & 4 & 4 & 0 \\
\hline M & 145 & Boulder Peak & 0 & & & \\
\hline $\mathrm{L}$ & 16 & Elk Mountain & 0 & & & \\
\hline $\mathrm{L}$ & 17 & Elk Mountain East & 0 & & & \\
\hline $\mathrm{L}$ & 22 & Badger & 0 & & & \\
\hline $\mathrm{L}$ & 24 & Lillian River & 0 & & & \\
\hline $\mathrm{L}$ & 32 & Mount Cameron & 0 & & & \\
\hline $\mathrm{L}$ & 35 & Cameron Creek & 0 & & & \\
\hline $\mathrm{L}$ & 42 & Baldy & 0 & & & \\
\hline $\mathrm{L}$ & 46 & Royal Creek & 0 & & & \\
\hline $\mathrm{L}$ & 64 & The Gargoyles & 0 & & & \\
\hline $\mathrm{L}$ & 109 & Christie & 2 & 3 & 2 & 1 \\
\hline
\end{tabular}



Publishing support provided by the U.S. Geological Survey Science Publishing Network, Tacoma Publishing Service Center

For more information concerning the research in this report, contact the Director, Forest and Rangeland Ecosystem Science Center U.S. Geological Survey

777 NW 9th St., Suite 400

Corvallis, Oregon 97330

http://fresc.usgs.gov/ 
